\title{
Forum
}

\section{Interview with Randall S. Schuler}

Randall S. Schuler is Professor, Human Resource Strategy; Director, Center of Strategic Human Resource Management and Director, Overseas Credit Programs in the Department of Human Resource Management at the School of Management and Labor Relations, Rutgers University.

He has written a number of articles on the topics of strategic human resource management and business strategies, human resource management and total quality management, and international human resource management.

His focus in these articles is how firms can systematically link the management of their human resources with the strategic needs of the business. His articles have appeared in European Management Journal, Organizational Dynamics, Administrative Science Quarterly, Academy of Management Executive, Academy of Management Journal, Industrial and Labor Relations Review, Human Resource Management, and the International Journal of Human Resource Management. In addition, Dr. Schuler has written numerous books on human resource management, organizational behavior and total quality management and has adapted his books to the Canadian, French, and English, Australian, and Spanish markets. His work is often translated and is currently being used throughout the world. He is past editor of the Human Resource Planning Society' s journal, Human Resource Planning.

He is also an active guest lecturer at universities around the world, including the London Business School, Singapore Institute of Management, Thunderbird, Manchester Business School, IMD, University of New South Wales, GSBA in Zurich, and the University of Zurich. 
Which are the most significant changes in Human Resource Management during the last 5 or 10 years?

The companies in the industrialized world will have to be more innovative and this requires effective HRM. They will also need better quality and customer service. This will also require better people management and better HRM.

HRM has changed more strategic and more global. Because increased competition companies seek to gain a sustainable competitive advantage, that can last a long time and cannot easily be imitated by competitors. As part of their strategies, some firms have started to use their approaches to managing human resources to gain a sustainable competitive advantage.

To gain sustainable competitive advantage through human resources firms need employees who add value to the organization by enhancing customers' perceptions of the products and services their organization has to offer. To be a source of sustainable competitive advantage, human resources must also be rare. If competitors can easily access the same pool of talent, then that talent provides no advantage against competitors. By being an employer of choice, organizations can gain access to the best available talent.

The best place to work is also the best place to invest: investors recognize that satisfied employees result in satisfied customers, especially in the services sector. Managers and employees who hate their jobs can't give the best possible service to customers.

Several recent studies have shown that better people management means better company performance. The approaches companies take to managing their human resources can translate into greater profitability, higher annual sales per employee, higher market value, and higher earnings-per-share growth.

Which significant changes in Human Resource Management do you predict for the next 10 years?

Major changes in future are connected with industry consolidation via mergers and acquisitions and increasing amount of International Joint Ventures. There will be more competition in all regions of the world and more cost/price pressure on Western companies from lower wage countries. To compete successfully companies need better HR management. It isn't possible without better training for HR professionals. HR would be more popular in universities with better students.

Which background is the most benefical for a future human resource manager and which competences does she or he need?

Master's degree in Human Resources/Industrial Relations or an MBA based on strong undergraduate degree is the most beneficial for HR professional. HR managers need competencies in business knowledge, change management, leadership, knowledge management and in HR functions. 
Which criteria are the most important in your opinion in evaluating the HRM function in a company?

I suggest to use the multiple stakeholder model. Firms are not as autonomous as we tend to think. In the long run, the company and its stakeholders are highly interdependent. A more realistic image portrays firms as nodes in a web of relationships that link together multiple companies and their employees, communities, government agencies, unions, and so forth.

Effective managers determine the interests of key stakeholders and work with them to find a solution that addresses each set of concerns. The partnership perspective for managing human resources is consistent with a increasing popular approach to strategic decision making, organizational performance evaluation, and strategic realignment - the balanced scorecard. The balanced scorecard approach enables companies to shift away from their habit of building operational and management control systems that address financial considerations exclusively. It combines financial performance with three other broad areas of concern: customers, internal processes, and the capacity of the organization for learning and growth.

To use the balanced scorecard approach, an organization develops performance indicators of success in each of the four domains and then assesses itself against these performance indicators. Financial indicators typically reflect the shareholders' perspective, and often include measures of revenue growth and mix, cost reduction and productivity improvement, and asset utilization. Core measures often used to assess performance in the customer domain include market share, account share, customer acquisition, customer retention, and customer satisfaction. For the domain of internal business processes, managers identify the internal processes that are most central to their value chain, thus they vary greatly depending on whether the organization competes on the basis of excellent customer service, innovation, providing low cost products and services, and so on. Finally, in the domain of learning and growth would be indicators that tap the organization's capacity for renewal and change. Employee-based measures such as level of satisfaction, retention rates, training opportunities, and skill development usually fall in this domain. HR should be evaluated against all the criteria listed.

Identifying the performance indicators to include in each domain is only the first step involved in using the balanced scorecard approach. More important to the success of this approach is understanding how to improve on the key indicators once they're identified. As many organizations soon discover, one way or the other, employees turn up at the center of most of the activities involved in implementing the balanced scorecard approach to strategic management and organization performance. Who the company hires, the training they receive, performance goals and the reward systems that motivate performance, performance assessment and feedback systems, executive 
development strategies - all of these activities can affect customer satisfaction and retention, the value added by internal operations, and the organization's capacity for future growth and learning.

In addition to a balanced scorecard approach a social audit is adopted by many companies. Whereas the balances scorecard focuses attention on the concerns of primary stakeholders mostly, a social audit assesses how well the organization addresses the concerns of stakeholders that many organizations consider secondary.

Used in combination these two approaches provide a comprehensive approach to assessing the quality of partnership an organization maintains with a wide range of stakeholders.

Which changes can you see in the relations between the employer and the employee in future? Which features are important for the future of trade unions?

Increasingly, a company's access to stockholder capital also will depend on its ability to satisfy multiple stakeholders-including unions. Employees and employers will continue to have different goals and objectives, unless there is greater sharing of ownership and profits.

Approaches to managing human resources can often provide organizations with effective solutions to the problem of how best to align the organization with the concerns of its multiple stakeholders, even when the concerns of different stakeholder groups seem to conflict. For example, when the compensation system is used to insure that employees are owners themselves, managers and other employees may put more effort into finding a solution that minimizes disruption while also meeting the organization's financial goals.

If there is no sharing unions will have a bigger opportunity to make gains in membership.

Organizations in East-Europe have been in continuous change during the last 10 years. How can the HRM function help to make changes faster and more successful?

A dynamic environment makes changes very important for almost every organization. Innovation and change are never-ending processes that become routine. Even the most successful organizations can't rest on prior successes. If they stop changing, competitors will woo away employees as well customers.

To be effective, organizations and their managers, employees, and contractors must learn how to deal creatively with day-to-day conditions that require adaptation. Successful organizational change almost always involves changing some approaches to managing people. 
Change management is a skill that HR professionals must have. HR professionals must help people and organizations change. Need to have partnership with all managers and employees in making changes.

How does the concept of a learning organisation help to make changes more succesful? What can these organisations do to increase organisational learning?

Learning and knowledge management are very important. What companies also need is the capacity to translate knowledge into new ways of doing business. Knowledge and learning capabilities are sources of competitive advantage when they add value and contribute to the company's ability to satisfy its stakeholders, including customers, employees, the community and shareholders.

For individuals, learning implies that a person change in some way. Similarly, organisational learning implies change - in management philosophies and practices, organisational culture and procedures.

Successful companies use learning to understand customers better and give them more of what they want. Employees understand that their own value in the labour market increases if they improve their own knowledge and skills. Companies that offer opportunities for self-improvement therefore benefit by attracting and retaining the best talent.

The value of a company's knowledge resources and learning capabilities depends on how difficult they are for competitors to imitate or replace. A learning culture that is embedded in a company's strategy and management practices is very difficult to imitate.

If knowledge resources and learning capabilities are recognised as essential to implementing company strategy, management practices ought to be oriented towards maximising them and making learning opportunities widely accessible and widely accessed.

Learning organisations encourage informal interactions that cross a company's boundaries. Flat, open and team-based structures often go hand-in-hand with a philosophy of empowerment, which places responsibility on employees for identifying and solving problems.

Many learning organisations develop a network of alliances with suppliers, customers and even competitors to gain new knowledge. Networking can improve the organisation's understanding of problems that lie beyond its own boundaries as well as motivate other members in the network to share knowledge and expertise to find creative solutions.

Learning organisations also understand that their chances of success are improved when they share knowledge with the community and work to help develop the intellectual capital of citizens. 
Turning the learning organisation from a concept into a source of competitive advantage requires organisational transformation. This demands resources and leadership commitment. 